\title{
Ozone concentrations in Kostaldea in the period 2001-2004
}

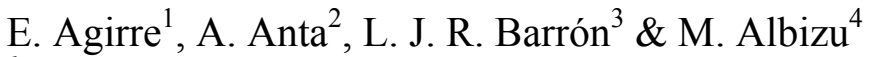 \\ ${ }^{1}$ University of The Basque Country, Department of Applied Mathematics, \\ Bilbao, Spain \\ ${ }^{2}$ Egailan, Vitoria-Gasteiz, Spain \\ ${ }^{3}$ University of The Basque Country, Department of Food Technology, \\ Vitoria-Gasteiz, Spain \\ ${ }^{4}$ Basque Government, Environmental Department, Bilbao, Spain
}

\begin{abstract}
This paper shows part of the results obtained in research work supported by the Basque Government. The aim of the work was to analyze the evolution of the tropospheric ozone $\left(\mathrm{O}_{3}\right)$ concentrations measured in five stations located on the coast of the Basque Country (North Central Spain) during the period 2001-2004. Ozone annual trends were similar at the different stations during 2001-2002, the ozone concentration increased considerably in 2003 and finally the ozone levels decreased in 2004, but were still greater than in the period 2001-2002. The year 2003 was a special case, with exceedances of ozone thresholds in summer and greater ozone concentrations than in the rest of the studied period. Results showed that exceedances of ozone values in Kostaldea occurred only in 2003. Consequently, the air quality of Kostaldea relative to ozone from 2001 to 2004 could be considered of good quality with specific episodes.
\end{abstract}

Keywords: tropospheric ozone, threshold values, trends, ozone cycles.

\section{Introduction}

It is well known that ozone is a photochemical pollutant, produced as a result of complex reactions among nitrogen oxides (NOx) and volatile organic compounds (VOCs) in the presence of sunlight [1]. High ozone levels cause human health problems and damage plants and certain materials and long exposures to ozone increase the negative effects [2]. Elevated ozone 
concentrations usually occur during the warm months (from April through September) [3]. As in many other areas, tropospheric ozone is considered to be one of the most important air pollutants in the Basque Country [4]. In this way, the Environmental Department of the Basque Government is interested in the control of the air quality in Kostaldea, where ozone levels increase specially in summer [5]. Therefore, the main goal of this study is to determine the variation of ozone at each station in Kostaldea in the period 2001-2004, determining the number of exceedances of ozone threshold values and the time when they occur. The legislation followed to establish the ozone threshold values was provided in the Council Directive CD 2002/03/EEC [6], which is summarized in Table 1.

Table 1: Ozone threshold values, long-term objective and target value for the protection of human health (CD 2002/03/EEC).

\begin{tabular}{lcc}
\hline Objective & Concentration $\left(\mu \mathrm{g} / \mathrm{m}^{3}\right)$ & Averaging time \\
\hline Alert threshold & 240 & 1 hour \\
Information threshold & 180 & 1 hour \\
Long-term objective & 120 & 8-hour average, daily maximum \\
Target value & 120 & 8-hour average, daily maximum \\
\hline
\end{tabular}

This is the newest directive relative to ozone threshold values, which sets the alert threshold as one-hour average concentration of $240 \mu \mathrm{g} / \mathrm{m}^{3}$ and a long-term objective $\left(120 \mu \mathrm{g} / \mathrm{m}^{3}\right)$ and a target value $\left(120 \mu \mathrm{g} / \mathrm{m}^{3}\right)$ for the protection of human health that should be attained in 2010 .

\section{Air quality monitoring data}

The air pollution network managed by the Environmental Department of the Basque Government measures hourly several meteorological parameters and air pollution variables at different stations in the Basque Country. This air pollution network is divided into eleven areas, as shown in Figure 1. The area on the coast considered in the present work, e.g. Kostaldea, is the area number 2. Hourly recorded values of $\mathrm{O}_{3}$ and meteorological variables such as hourly registered temperature, pressure, relative humidity, solar radiation, wind speed and wind direction were used in the present study.

The matrix of data collected has 35.064 entries (hourly measures of $\mathrm{O}_{3}$ and meteorological variables in the period 2001-2004) for each station. Some of the stations in Kostaldea (Elgoibar, Jaizkibel and Avenida de Tolosa) have been recently added to the air quality network and they have no valid values in the whole period of the study. Owing to this, the following five stations were selected for the work: Mundaka (lat.: $43^{\circ} 24^{\prime} 22^{\prime \prime}$, long.: $2^{\circ} 42^{\prime} 14^{\prime \prime}$, alt.: 116),

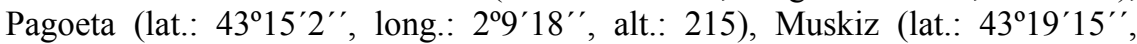

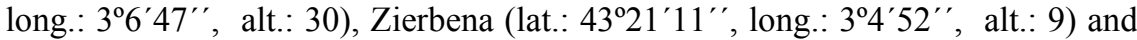

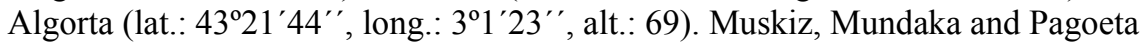
registered ozone values during the period 2001-2004, but Algorta and Zierbena 
stations measured ozone values from 2002. Muskiz, Zierbena, Algorta and Mundaka are located in urban areas and Pagoeta is situated in a rural zone.

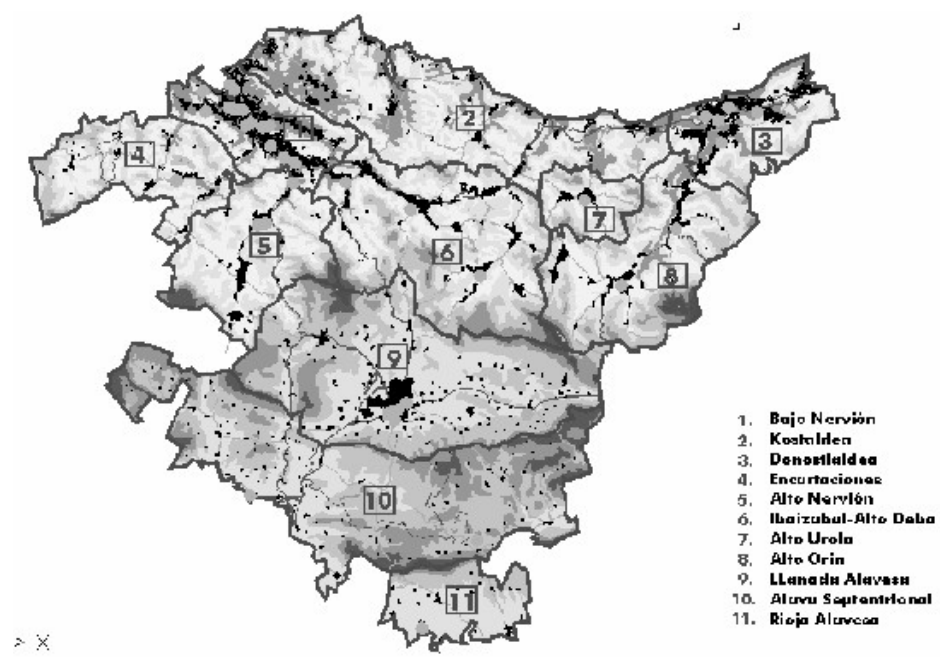

Figure 1: The eleven areas in the air pollution network (Basque Government). Kostaldea is the area number 2 .

\section{Results and discussion}

Firstly, the values of the following statistics were calculated: the number of valid and missing values, mean, standard deviation, maximum, minimum and the percentiles 50, 75 and 95 of $\mathrm{O}_{3}$ at each station from 2001 to 2004, respectively. A monthly study would show the annual ozone trend at each station. Figures 2 , 3, 4 and 5 depict monthly ozone evolution at Muskiz during the period 20012004. It is noticeable that there were no significant differences between the average value and the median value. The average ozone values in 2003 were greater than the average ozone values during the half period 2001-2002, but after 2003, the average ozone value and the percentiles 50 and 95 in 2004 decreased, being however higher than those values registered through 2001-2002. Furthermore, Figures 2, 3, 4 and 5 show that the ozone values in July were lower than the ozone concentrations in June and August in the period 2001-2004. It is not easy to find the causes of this effect in a first step, but the decrease of days with intrusions of Saharan air and the absence of the Ebro Valley breeze in July could be some of the meteorological factors to be studied in order to explain the lower ozone values measured in July from 2001 to 2004. 


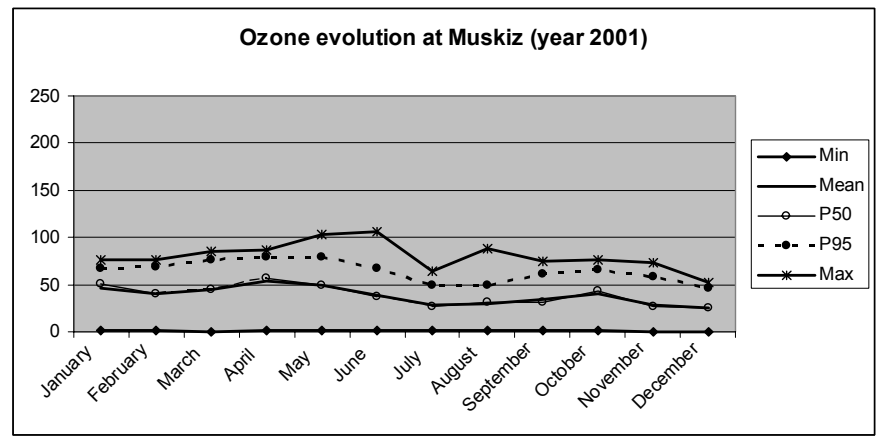

Figure 2: Ozone evolution at Muskiz during 2001.

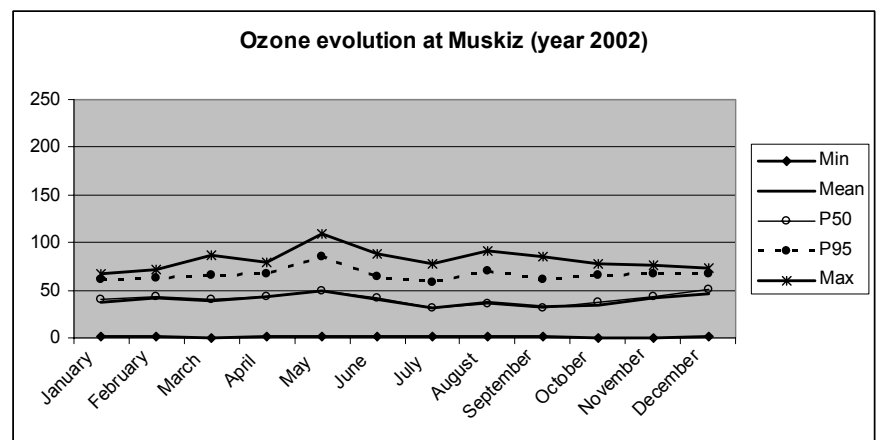

Figure 3: Ozone evolution at Muskiz during 2003.

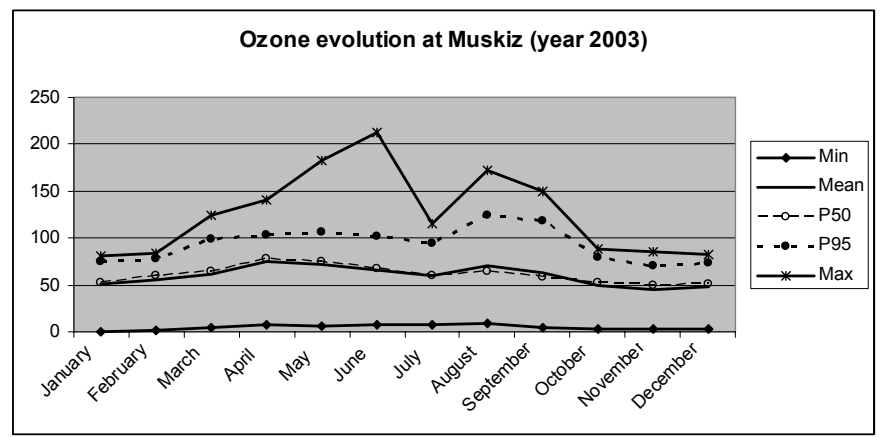

Figure 4: Ozone evolution at Muskiz during 2003. 


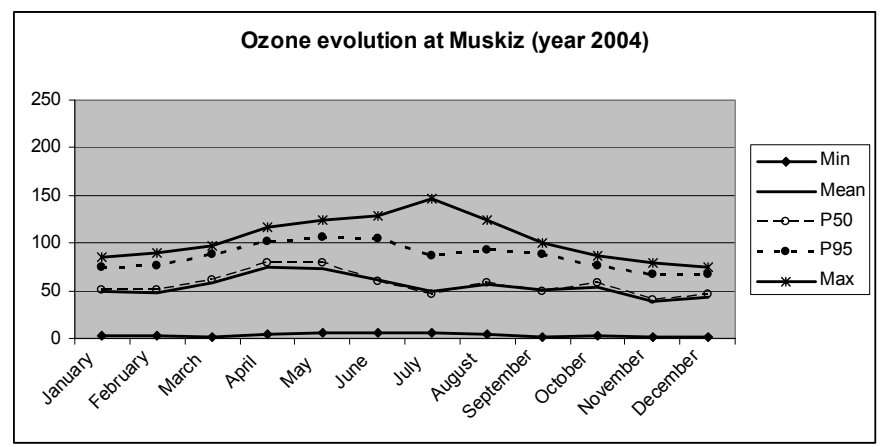

Figure 5: Ozone evolution at Muskiz during 2004.

The yearly evolution of ozone was studied, with an average annual value ranging from $38.50 \mu \mathrm{g} / \mathrm{m}^{3}$ at Muskiz during 2001 to $78.93 \mu \mathrm{g} / \mathrm{m}^{3}$ at Pagoeta during 2003. The values of the 95 percentiles corresponding to these means were $70 \mu \mathrm{g} / \mathrm{m}^{3}$ at Muskiz during 2001 and $120 \mu \mathrm{g} / \mathrm{m}^{3}$ at Pagoeta during 2003. Generally, the ozone values were comparatively higher at Pagoeta. Figure 6 represents the ozone average values measured at the five stations in the period 2001-2004, where the above fact could be observed.

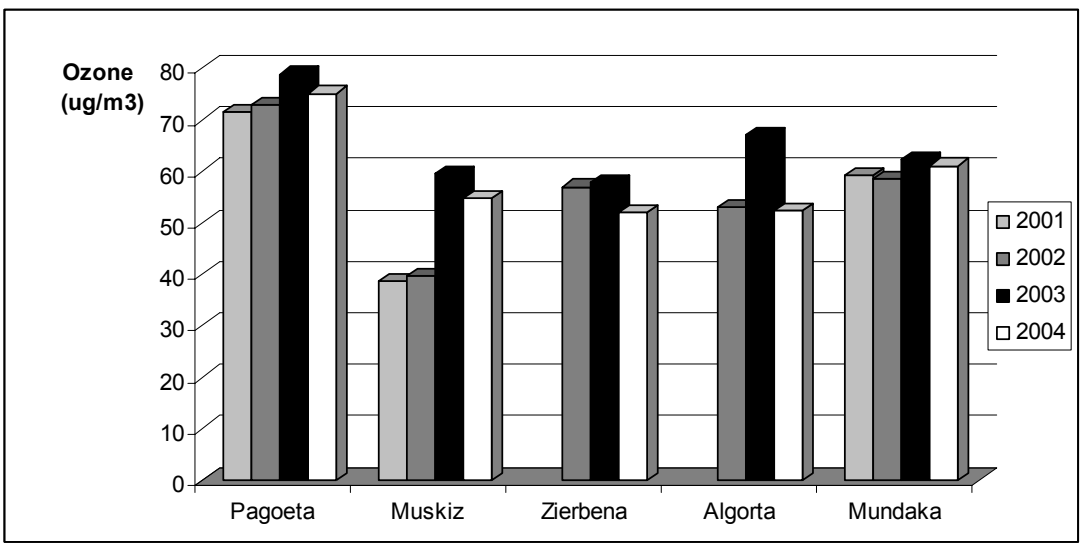

Figure 6: Ozone average values in Kostaldea from 2001 to 2004.

Ozone concentrations were greater during the warm season (from April to September), and as it could be proved in the whole period study, the ozone annual trend had no relevant difference in a comparative way among the different years from 2001 to 2004, except year 2003, when due to the hot temperatures measured in 2003 the ozone concentrations during April 2003September 2003 reached the peak. In fact, the ozone maximum values registered in 2003 were greater than the ozone maximum values measured from 2001 to 
2002, but the ozone maximum values recorded in 2004 decreased, being similar to those recorded in 2001 and 2002, as shown in Table 2.

Table 2: Ozone maximum values $\left(\mu \mathrm{g} / \mathrm{m}^{3}\right)$ at each station during 2001-2004.

\begin{tabular}{lccccc}
\hline & Muskiz & Zierbena & Algorta & Mundaka & Pagoeta \\
\hline $\mathrm{Max} \mathrm{O}_{3}(2001)$ & 106 & - & - & 180 & 176 \\
$\mathrm{Max} \mathrm{O}_{3}(2002)$ & 109 & 139 & 121 & 146 & 162 \\
$\mathrm{Max} \mathrm{O}_{3}(2003)$ & 212 & 202 & 209 & 195 & 230 \\
$\mathrm{Max} \mathrm{O}_{3}(2004)$ & 146 & 133 & 125 & 166 & 157 \\
\hline
\end{tabular}

This issue was considered as proof of the influence of meteorology on ozone concentrations [7].

The diurnal cycle of ozone was also observed. Figure 7 shows that ozone levels reached their peak between 13:00 and 15:00, when temperature and solar radiation values were the highest and after the sun had time to react totally with the emissions produced in the morning hours.

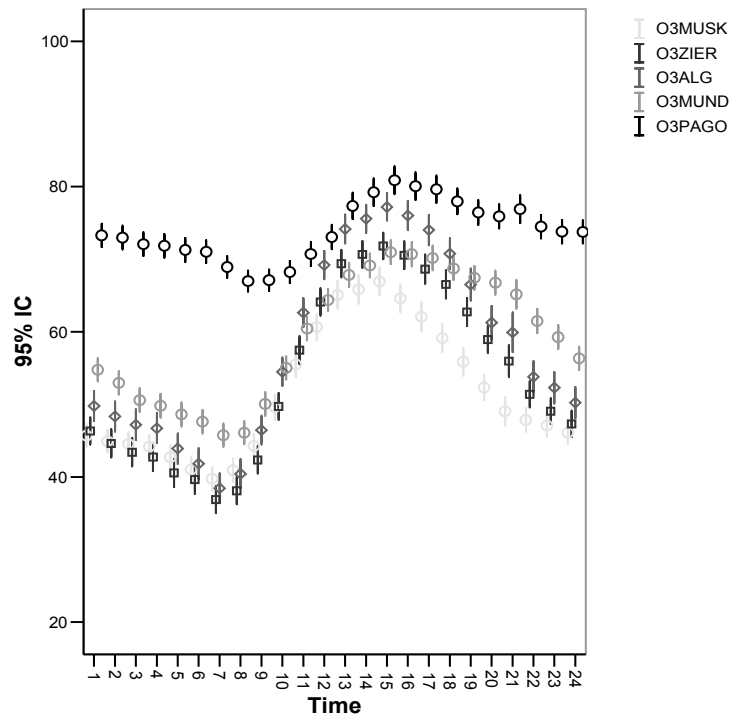

Figure 7: The daily ozone cycle in Kostaldea (2001-2004).

About ozone threshold values, there was no exceedance of the alert threshold $\left(240 \mu \mathrm{g} / \mathrm{m}^{3}\right)$. Table 2 presents the greatest ozone concentration of $230 \mu \mathrm{g} / \mathrm{m}^{3}$, measured at Pagoeta in 2003. However, the population information threshold $\left(180 \mu \mathrm{g} / \mathrm{m}^{3}\right)$ was exceeded 12 times at Pagoeta, 11 times at Algorta, 8 times at 
Muskiz, 6 times at Mundaka and 5 times at Zierbena, but only in the hot summer of 2003. Consequently, it could be thought that if summers get warmer more frequent exceedances would be expected. The mentioned exceedances occurred during four days (29 May 2003, 21 June 2003, 4 August 2003 and 8 August 2003). In the majority of the stations the population information threshold exceedances lasted five or six hours. Table 3 shows that those exceedances at Pagoeta began at noon and finished six hours later. Finally, the target value (120 $\mu \mathrm{g} / \mathrm{m}^{3}$, eight-hour averaged) was exceeded 343 times at Pagoeta, 225 times at Algorta, 78 times at Mundaka, 45 times at Muskiz and 43 times at Zierbena from March to September in 2003.

Table 3: Days and time of exceedances of the information threshold $\left(180 \mu \mathrm{g} / \mathrm{m}^{3}\right)$ at Pagoeta in the period 2001-2004.

\begin{tabular}{cccc}
\hline Station & \multicolumn{2}{c}{ Day and time } & Ozone $\left(\mu \mathrm{g} / \mathrm{m}^{3}\right)$ \\
\hline \multirow{5}{*}{ Pagoeta } & 4 August 2003 & $12: 00$ & 183 \\
& 4 August 2003 & $13: 00$ & 205 \\
& 4 August 2003 & $14: 00$ & 223 \\
& 4 August 2003 & $15: 00$ & 216 \\
& 4 August 2003 & $16: 00$ & 206 \\
& 4 August 2003 & $19: 00$ & 184 \\
& 8 August 2003 & $13: 00$ & 207 \\
& 8 August 2003 & $14: 00$ & 230 \\
& 8 August 2003 & $15: 00$ & 214 \\
& 8 August 2003 & $16: 00$ & 204 \\
& 8 August 2003 & $17: 00$ & 192 \\
& 8 August 2003 & $18: 00$ & 190
\end{tabular}

\section{Conclusions}

Ozone concentrations in Kostaldea followed a similar trend during each year of the period 2001-2004 with higher ozone concentrations from April to September than in the rest of the year. A special case was year 2003, when owing to the high summer temperatures ozone concentrations that year were greater and the maximum values were notably higher than in the rest of the studied period. The diurnal cycle was also studied and it showed that the highest ozone concentrations were measured between noon and the late afternoon. Finally, the ozone evolution observed during the whole studied period established an increasing trend: ozone concentrations in 2003 were greater than in the period 2001-2002 and ozone levels decreased in 2004, but they were greater than the ozone levels in 2001-2002. Finally, it must be said that comparisons among the different stations concluded that the greatest ozone levels were found in Pagoeta, a rural station in Kostaldea. 
In reference to the exceedances, ozone levels never exceeded the population warning threshold. The population information threshold was exceeded 42 times in Kostaldea, being Pagoeta the station with more exceedances. All those exceedance times were measured in the summer of 2003, at noon, and they lasted between three and six hours. At the same time, several ozone episodes were detected specially during 2003, with exceedances of the target value.

\section{Acknowledgements}

The authors wish to thank the Environmental Department of the Basque Government for providing data from their air pollution network and for financially helping the development of this work.

\section{References}

[1] Finlayson-Pitts, B.J., Pitts, J.N., Atmospheric Chemistry: fundamentals and experimental techniques, J. Wiley, New York, 1986.

[2] WHO. Health aspects of air pollution with particulate matter, ozone and nitrogen dioxide. Report of a WHO Working Group, Bonn, Germany 13-15 January 2003.

[3] Fiala j., Cernikovsky L., de Leeuw F., Kurfuerst P. (2003). Air pollution by ozone in Europe in summer 2003. European Environmental Agency, Topic Report 3/2003.

[4] Basque Government. The air quality in the Basque Country in the period 1996-2000. Vitoria-Gasteiz, 2001.

[5] Basque Government. The environmental report in the Basque Country 2004. Air and noise, 10, Vitoria-Gasteiz, 2004.

[6] Official Journal of the European Communities (2002). Directive 2002/3/EC of the European Parliament and of the Council of 12 February 2002 relating to ozone in ambient air, OJ L 67, 3.3.2002.

[7] Vukovich F.M. Regional-scale boundary layer ozone variations in the eastern United Status and their association with meteorological variations. Atmospheric Environment 29, pp. 2259-2273, 1995. 